\title{
Prospective Analysis Of The Algerian Economic Growth By 2025: Structural Analysis
}

Dr. Rachid Toumache, ENSSEA, Algeria

Dr. Khaled Rouaski, ENSSEA, Algeria

\begin{abstract}
The aim of this study is to assess the economic growth in Algeria and to determine the set of variable impacting it on different periods. It relies on structural analysis approach based on an investigation method using the software MICMAC (matrix of cross-influence, applied multiplication to a ranking) which was developed by the Institute of Computing Innovation 3IE following the request of Investigation Laboratory on Prospective, Strategy and Organization LIPSOR. The structural analysis can define the key variables of the system (VCS) to catch the most influential variables on economic growth during three time intervals: the near past (direct impact), the actual period (indirect influence) and the long run (potential indirect impact) bearing in mind that the horizon of our study is 2025. The results show the most influential variables ranked during each period as follows: The near past (the direct influence): the economic system, public spending, the regulation, foreign reserves and price of oil barrel, unemployment, inflation and SMEs. The actual period (the indirect influence): the economic system, business climate, FDI, the price of the oil barrel, active population, occupied population, external debt. In addition to other variables having a less influence: unemployment, SMEs, inflation and foreign trade. The long run (potential indirect influence) by 2025: The economic system, public spending, the regulation, foreign reserves, unemployment, FDI, inflation, business climate, currency, occupied population, the price of the oil barrel, saving. Other variables have a moderate influence: national security, capital, exchange rate, financial system, active population, IT, informal sector, SMEs, external trade, external debt, demographic growth and the interest rate.
\end{abstract}

Keywords: Economic Growth; Growth Process; Prospective; MICMAC; VCS; Direct And Indirect Potential Influence; Algerian Economic Horizon Of 2025

\section{INTRODUCTION}

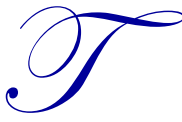

he Algerian economy has the potential of being part of emerging countries either by its human or material potentials, its important resources permit to fund real future perspectives. Nowadays, the Algerian economy returned to the growth path after being on the verge of suffocation.

The State's means of intervention is consolidated in the favor of sustained reconstitution of macroeconomic equilibriums. The implementation of the five-year plan of growth-support (2005-2009) to strengthen the growth allowed generating the growth via factors of supply and demand but also by providing areas of intervention to public investments and national companies. In addition to their multiplier effects and the sensitive impact on a range of fields (employment, infrastructures, revenues) the evaluation of these plans cannot deduct the return of the State as the main actor of the economic and social life. Also, Algerian authorities have conducted several economic policies during different periods and according to the prevailing situations, with the main objective of economic overhaul and to ensure an economic start to improve the population's living conditions.

The 2000-2010 decade was marked by an improvement in macroeconomic aggregates, favorable oil market with rising oil prices, and a very low foreign debt. The government, aware of the need to develop and strengthen the hydrocarbon sector, revived the industrialization and different public investment programs funded by the public treasury were launched to achieve the development's goals. 
The first plan of 2001-2004 is that of supporting economic recovery, the background is that of 2005-2009, complementary to support growth (PCSC), followed by 2010-2014 came in addition to and aimed mainly the development of the industrial sector, with special support for the development of SMEs and SMIs.The new five-year development plan 2015-2019 is in line with the previous development plans and follows the president instructions aiming at making it more complete and ensuring national and local requirements to improve its impact on local development and human capital, with a stress to enhance the competitiveness of all economic sectors.

\section{IDENTIFYING THE VARIABLES, SAMPLE CHARACTERISTICS AND PROSPECTIVE ANALYSIS}

To engender the entire variable influencing the growth process in Algeria, we will try the structural analysis by applying MICMAC method with the following steps:

\subsection{Identifying The Variables}

This step consists of choosing in a relative exhaustive way the elements of the system being the most pertinent in order to reach the goal: determining the key variables of the system (the Algerian economic growth). Here, we identified a set of variables influencing the Algerian economic growth (whether positively or negatively). These variables cover several fields: economic, politics, social.

Table 1. Abbreviations and Descriptions Variables

\begin{tabular}{|c|c|c|c|}
\hline $\mathbf{N}$ & Complete Name & Abbreviation & Description \\
\hline 1 & Active Population & Pop. Act & All persons providing available labor to the production of goods and services \\
\hline 2 & Capital & Cap & Financial and non financial assets held by economic agents, material capital \\
\hline 3 & Foreign Reserves & Res, Chag & Amount in foreign currencies of the external trade surplus \\
\hline 4 & IT & Tic & $\begin{array}{l}\text { Information technologies and communication, mobile phones, internet ,PC, } \\
\text { radio,... }\end{array}$ \\
\hline 5 & Inflation & Inf & General continue increase of goods and services price level \\
\hline 6 & FDI & Ide & $\begin{array}{l}\text { The process of creating businesses or the entrepreneurships (private } \\
\text { investment) }\end{array}$ \\
\hline 7 & Public Spending & Dep. Pub & A lever to act on the economic / social life \\
\hline 8 & Business Climate & Clm.Affr & $\begin{array}{l}\text { Management of public affairs and the whole problems hindering it: bribery, } \\
\text { governance. }\end{array}$ \\
\hline 9 & Financial System & Sys.Fin & The financial institutions and the capital markets ensuring funds \\
\hline 10 & Regulation & $\operatorname{Rg~L}$ & Different laws, regulation of the State for political, economic field \\
\hline 11 & FDI & Ide & Access of foreign investors to invest in Algeria \\
\hline 12 & External Trade & Imp.Exp & $\begin{array}{l}\text { Trade between Algeria and the rest of the world or the external trade in terms } \\
\text { of imports/exports }\end{array}$ \\
\hline 13 & Financial Crisis & Crs.Fin & Supprime crisis $(2008)$ \\
\hline 14 & External Debt & Det.Ex & External debt of Algeria, expecially toward the World Bank \\
\hline 15 & Informal Sector & Sect. Inf & Unstructured activities by laws/ regulation \\
\hline 16 & Exchange Rate & Tx.Chang & Equivalency of foreign currencies vis -à-vis Algerian Dinar \\
\hline 17 & Interest Rate & Tx. Intrt & Rate imposed by the financial system :central bank and commercial banks \\
\hline 18 & National Security & Secrt. Ntl & Political and social stability and the influencial factors \\
\hline 19 & Geographic Localisation & Loc. Geo & The geographic position of Algeria and its influence on the Economic activity \\
\hline 20 & Demographic Growth & Crss. Demg & Growth rate of the population \\
\hline 21 & Literacy Rate & Tx.Alph & Access to education or the enrollment level of population \\
\hline 22 & Innovation R\&D & Invt. R/D & $\begin{array}{l}\text { Investment in knowledge and creating new technologies to Produce goods and } \\
\text { services }\end{array}$ \\
\hline 23 & Economic System & Sys. Eco & $\begin{array}{l}\text { The economic policy followed by the State to ensure a sound economic } \\
\text { management }\end{array}$ \\
\hline 24 & Unemployment & Chmg & Inactivity of People Seeking A Job \\
\hline 25 & Saving & Eprg & Share of Households' Savings \\
\hline 26 & Currency & Mne & Exchange instrument between economic agents \\
\hline 27 & Oil Barrel Price & Prx. Brl & Price of oil barrel at world markets \\
\hline 28 & Occupied Population & Pop.Occp & Population having a job and producing goods and services \\
\hline
\end{tabular}


The goal was to make the economy is supported by private and public companies, dynamic and open to various forms of foreign partnerships that contribute to the diversification of domestic production, decreasing import bill reduction unemployment, all this by encouraging the adoption of investment policies with incentive measures and facilitators. There was the promulgation of the orientation law for the promotion of SMEs.

Also, as part of its international economic openness, Algeria adopted a policy of encouraging foreign investment and to sign balanced partnerships, to benefit from technology transfer, acquire the know-how and managerial skills necessary to diversify domestic production and export. So the important question today in Algeria about the economic outlooks.

\subsection{The Input Matrix (Matrix of Direct Influence)}

The structural analysis first serves as a tool structuring ideas. It gives the possibility to describe a system via a matrix putting in relation all its constitutive elements. With the Direct Influences Matrix (DIM), we can describe direct influence relationships between the variables of our system.

Table 2. Direct Influence Matrix

\begin{tabular}{|c|c|c|c|c|c|c|c|c|c|c|c|c|c|c|c|c|c|c|c|c|c|c|c|c|c|c|c|c|}
\hline & $\begin{array}{l}:-2 \\
\overline{0}\end{array}$ & 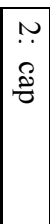 & 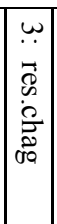 & & $\left|\begin{array}{l}: \\
. \\
E \\
\end{array}\right|$ & $\begin{array}{c}\stackrel{P}{ } \\
\bar{O} \\
\Xi\end{array}$ & 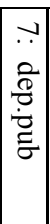 & 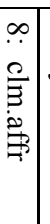 & 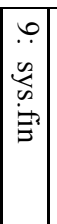 & 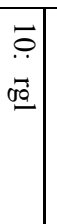 & & 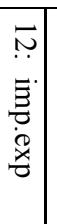 & 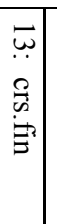 & 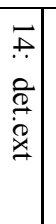 & 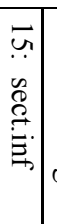 & 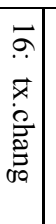 & $\begin{array}{l}\vec{x} \\
\vec{x} \\
\stackrel{\Xi}{\Xi} \\
\vec{\Xi}\end{array}$ & 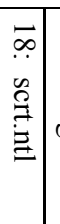 & $\begin{array}{c}\overrightarrow{0} \\
\dot{0} \\
\varnothing \\
0 \\
0 \\
0 \\
0\end{array}$ & 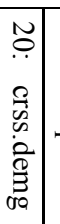 & $\begin{array}{l}\stackrel{N}{\cdot} \\
\vec{x} \\
\hat{\tilde{\theta}} \\
\frac{\sigma}{\sigma}\end{array}$ & & 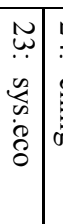 & & & & & $\begin{array}{l}1 \\
0 \\
0 \\
\square \\
0 \\
0 \\
0 \\
0 \\
8\end{array}$ \\
\hline pop.act & 0 & 0 & 0 & 1 & 1 & 2 & 3 & 1 & 1 & 2 & \begin{tabular}{|l|}
1 \\
\end{tabular} & 2 & 0 & 0 & 3 & 0 & 1 & 2 & 0 & 1 & 1 & 1 & 2 & 3 & 3 & \begin{tabular}{l|l}
0 & ( \\
\end{tabular} & 0 & 2 \\
\hline 2: cap & 2 & 0 & 2 & 0 & 2 & 2 & 2 & 1 & \begin{tabular}{|l|}
1 \\
\end{tabular} & 3 & 2 & 2 & 1 & 2 & 2 & 0 & 2 & 1 & 0 & 1 & 3 & 1 & 1 & 2 & 2 & ( & \begin{tabular}{l|l}
0 & 2 \\
\end{tabular} & 2 \\
\hline 3: res.chag & 2 & $\mathrm{P}$ & 0 & 2 & 0 & 2 & $\mathrm{P}$ & 1 & \begin{tabular}{|l|}
2 \\
\end{tabular} & 2 & \begin{tabular}{|l|l|}
2 \\
\end{tabular} & $\mathrm{P}$ & 2 & 3 & 1 & 0 & 1 & 1 & 0 & 0 & 2 & 1 & 2 & 1 & 2 & \begin{tabular}{l|l}
2 & ( \\
\end{tabular} & \begin{tabular}{l|l}
0 & 3 \\
\end{tabular} & 3 \\
\hline 4: tic & 2 & 2 & 1 & \begin{tabular}{|l|}
0 \\
\end{tabular} & $0 \mid$ & 2 & 2 & 1 & $2 \mid$ & 2 & \begin{tabular}{|l|l}
1 \\
\end{tabular} & 2 & 0 & 0 & 1 & 0 & 0 & 1 & 0 & 2 & 3 & 2 & 2 & 2 & 0 & \begin{tabular}{l|l}
0 & 1 \\
\end{tabular} & \begin{tabular}{l|l}
0 & 2 \\
\end{tabular} & 2 \\
\hline 5: infl & 1 & 1 & 2 & 1 & 0 & 2 & $\mathrm{P}$ & 1 & \begin{tabular}{|l|}
1 \\
\end{tabular} & 3 & \begin{tabular}{|l|l|}
1 \\
\end{tabular} & 1 & 1 & 0 & 2 & 2 & 2 & 1 & 0 & 0 & 0 & 0 & 1 & 0 & 2 & \begin{tabular}{l|l}
3 & 1 \\
\end{tabular} & $\begin{array}{ll}0 & 2 \\
\end{array}$ & 2 \\
\hline 6: pem & 2 & \begin{tabular}{|l|}
1 \\
\end{tabular} & \begin{tabular}{|l|}
1 \\
\end{tabular} & \begin{tabular}{|l|}
2 \\
\end{tabular} & \begin{tabular}{|l|}
1 \\
\end{tabular} & \begin{tabular}{l|l}
0 \\
\end{tabular} & \begin{tabular}{|l|}
2 \\
\end{tabular} & 1 & \begin{tabular}{|l|}
1 \\
\end{tabular} & 1 & \begin{tabular}{|l|l|}
2 \\
\end{tabular} & 2 & \begin{tabular}{l|l}
0 \\
\end{tabular} & 0 & 2 & 0 & 2 & 0 & 0 & 1 & 0 & 1 & 0 & 2 & 1 & \begin{tabular}{l|l}
2 & 0 \\
\end{tabular} & $\begin{array}{lll}0 & 2 \\
\end{array}$ & 2 \\
\hline 7: dep.pu & 2 & $\mathrm{P}$ & 3 & 1 & 2 & 2 & 0 & 2 & \begin{tabular}{|l|l}
1 & \\
\end{tabular} & 2 & \begin{tabular}{|l|l|}
2 \\
\end{tabular} & 2 & 1 & 0 & 2 & 0 & 1 & 2 & 0 & 1 & 2 & 2 & 3 & 2 & 1 & & \begin{tabular}{l|l}
0 & 2 \\
\end{tabular} & 2 \\
\hline 8: clm.af & 2 & 2 & 2 & 0 & 2 & 2 & 2 & 0 & 2 & 3 & \begin{tabular}{|l|l|}
3 \\
\end{tabular} & 1 & 0 & 0 & 1 & 0 & \begin{tabular}{l|l}
0 \\
\end{tabular} & 1 & 0 & 0 & 0 & 0 & 2 & 2 & 0 & \begin{tabular}{l|l}
0 & $(1$ \\
\end{tabular} & 0 & 1 \\
\hline 9: sys.fin & 1 & 2 & 2 & 1 & 1 & 3 & 0 & 2 & 0 & 1 & 2 & 1 & 2 & 0 & 2 & 2 & 3 & 1 & 0 & 0 & 0 & 1 & 1 & 2 & 3 & 2 & 0 & 1 \\
\hline 10: $\mathrm{rgl}$ & 3 & $\mathrm{P}$ & 3 & 2 & 2 & 2 & $\mathrm{P}$ & 2 & $2 \mid$ & 0 & 2 & 3 & 1 & 3 & 2 & 2 & 2 & $\mathrm{P}$ & 0 & 0 & 2 & 1 & 3 & 2 & 0 & \begin{tabular}{l|l}
2 & 1 \\
\end{tabular} & \begin{tabular}{l|l}
0 & 1 \\
\end{tabular} & 0 \\
\hline 11: ide & 2 & 3 & 2 & 2 & 2 & 1 & \begin{tabular}{|l|}
2 \\
\end{tabular} & 1 & 1 & 2 & 0 & 2 & 0 & 1 & 1 & 0 & 2 & 1 & 0 & 0 & 0 & 1 & 2 & 2 & 0 & \begin{tabular}{l|l}
0 & $(1$ \\
\end{tabular} & 0 & 1 \\
\hline 12: imp.exp & 1 & 1 & 3 & \begin{tabular}{|l|}
1 \\
\end{tabular} & $2 \mid$ & 2 & 2 & 0 & \begin{tabular}{|l|}
0 \\
\end{tabular} & 2 & 1 & 0 & 0 & 1 & 2 & 0 & 0 & 1 & 0 & 0 & 0 & 0 & 1 & 2 & 0 & 0 & 2 & 1 \\
\hline 13: crs.fin & 1 & 2 & $\mathrm{P}$ & 2 & 1 & 1 & 1 & 0 & 2 & 1 & 1 & 2 & 0 & 1 & 0 & 2 & 1 & 0 & 0 & 0 & 0 & 1 & 0 & 0 & 1 & 0 & \begin{tabular}{l|l}
3 & 1 \\
\end{tabular} & 0 \\
\hline 14: det.ext & 1 & 1 & 3 & 1 & 1 & 1 & 1 & 1 & \begin{tabular}{|l|}
0 \\
\end{tabular} & 2 & 2 & 2 & 1 & 0 & 0 & 1 & 0 & 2 & 0 & 0 & 0 & 0 & 2 & 1 & 1 & 0 & \begin{tabular}{l|l}
0 \\
\end{tabular} & 1 \\
\hline 15: sect.inf & 2 & 1 & 1 & 1 & 2 & 2 & 2 & 1 & \begin{tabular}{|l|l|}
1 & \\
\end{tabular} & 2 & \begin{tabular}{|l|l|}
0 \\
\end{tabular} & 1 & 0 & 0 & \begin{tabular}{l|l}
0 & \\
\end{tabular} & 2 & 1 & 2 & \begin{tabular}{|l|l|}
0 & \\
\end{tabular} & 1 & 1 & 0 & 1 & 3 & 1 & 0 & 0 & 2 \\
\hline 16: tx.chang & 0 & 3 & 2 & 1 & 3 & 2 & 3 & 1 & 2 & 1 & 1 & 3 & \begin{tabular}{l|l}
0 & \\
\end{tabular} & 2 & 2 & 0 & 2 & 0 & 0 & 0 & 0 & 0 & 1 & 1 & \begin{tabular}{l|l}
3 \\
\end{tabular} & 2 & \begin{tabular}{l|l}
2 & 1 \\
\end{tabular} & 0 \\
\hline 17: tx.intrt & 0 & 0 & 0 & 0 & 2 & 2 & 0 & 0 & 2 & 2 & 1 & 0 & 0 & 1 & 2 & 0 & 0 & 0 & 0 & 0 & 0 & 0 & 0 & 2 & 2 & 2 & 0 & 0 \\
\hline 18: scrt.ntl & 1 & 22 & 1 & 2 & 1 & 2 & 2 & 2 & 2 & 3 & 3 & 2 & 2 & 2 & 2 & 0 & 2 & 0 & 0 & 2 & 2 & 2 & 1 & 2 & 1 & 1 & 0 & 0 \\
\hline 19: loc.geo & 1 & 22 & \begin{tabular}{|l|}
0 \\
\end{tabular} & \begin{tabular}{|l|}
0 \\
\end{tabular} & 1 & 1 & 2 & 0 & \begin{tabular}{|l|}
0 \\
\end{tabular} & 0 & \begin{tabular}{|l|l|}
2 \\
\end{tabular} & 1 & 0 & 0 & 0 & 0 & 0 & 2 & 0 & 0 & 0 & 0 & 0 & 1 & 0 & 0 & $0 \quad 0$ & 0 \\
\hline 20: crss.demg & 3 & 1 & 1 & 2 & 2 & 2 & 2 & 0 & \begin{tabular}{|l|}
0 \\
\end{tabular} & 2 & \begin{tabular}{|l|l|}
2 \\
\end{tabular} & 2 & \begin{tabular}{l|l}
0 \\
\end{tabular} & 0 & 1 & 0 & 0 & 1 & 0 & 0 & \begin{tabular}{|l|l|}
1 \\
\end{tabular} & 0 & 0 & 1 & 0 & 0 & 0 & 2 \\
\hline 21: tx.alph & 2 & 1 & 0 & 1 & 0 & 2 & 2 & 1 & 0 & 1 & 1 & 0 & 0 & 0 & 2 & 0 & 0 & 1 & 0 & 1 & 0 & 1 & 1 & 2 & 0 & 0 & 0 & 1 \\
\hline 22: invt.r/d & 1 & 2 & 0 & 2 & 0 & 2 & 2 & 0 & \begin{tabular}{|l|}
0 \\
\end{tabular} & 1 & 2 & 1 & 0 & 0 & 0 & 0 & 1 & 1 & 0 & 1 & 2 & 0 & 0 & 1 & 0 & 0 & 0 & 1 \\
\hline 23: sys.eco & 2 & 2 & 3 & 3 & 3 & 2 & \begin{tabular}{|l|}
3 \\
\end{tabular} & $\mathrm{P}$ & 2 & 3 & 2 & 2 & 2 & 3 & 2 & 0 & 2 & 4 & 0 & 1 & 1 & 2 & 0 & 3 & 1 & 2 & 1 & 2 \\
\hline 24: chmg & 3 & 2 & 0 & 1 & 2 & 3 & 3 & 0 & 1 & 2 & 1 & 1 & 0 & 0 & 2 & 0 & 2 & 2 & 0 & 2 & 0 & 1 & 1 & 0 & 3 & 0 & 0 & $P$ \\
\hline 25: eprg & 0 & 1 & 0 & 2 & 2 & 1 & 0 & 0 & 2 & 1 & 1 & 1 & 0 & 1 & 0 & 2 & 0 & 0 & 0 & 0 & 0 & 0 & 1 & 1 & 0 & 1 & 0 & 0 \\
\hline 26: mne & 0 & 1 & 2 & 1 & 3 & 1 & 1 & 0 & 2 & 3 & 1 & 2 & 0 & 0 & 1 & $\mathrm{P}$ & 3 & 0 & 0 & 0 & 0 & 0 & 1 & 1 & 2 & 0 & 0 & 0 \\
\hline 27: Prx.brl & 0 & 2 & $\mathrm{P}$ & 1 & 0 & 0 & 3 & 0 & 0 & 3 & 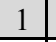 & 2 & 2 & 2 & 0 & 1 & 0 & 0 & 0 & 0 & 0 & 0 & 3 & 1 & 0 & 0 & 0 & 0 \\
\hline 28: pop.oсcр & 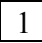 & 1 & 1 & 2 & 2 & 1 & $\mathrm{P}$ & 0 年 & \begin{tabular}{|l|l|}
1 \\
\end{tabular} & 2 & 0 & 1 & 0 & 0 & & 0 & & 2 & 0 & 1 & 1 & 1 & 1 & 3 & 2 & 0 & 0 & 0 \\
\hline
\end{tabular}


The filling of the matrix is generally qualitative.

0 : means no influence, inexistent relationship between the variables $i$ and $j$.

1: weak influence

2: medium influence

3: strong influence

P: potential influence.

We recall that for building the structural analysis matrix, we put the variables in rows and columns. We fill the matrix either in rows by noting the influence of each row variable on all other column variables, or in columns by noting the variables' dependence in columns to those in rows.

\subsection{Characteristics of the Dim}

The table presents the numbers $0,1,2,3, \mathrm{P}$ of the matrix and displays the rate of filling calculated by the ratio of a number of DIM values other than 0 and the total number of the matrix elements.

Table 3. Characteristics of the DIM

\begin{tabular}{l|c}
\hline \multicolumn{1}{c}{ Size of the matrix } & $\mathbf{2 8}$ \\
\hline Iteration number & 4 \\
\hline Number of 0 & 286 \\
\hline Number of 1 & 186 \\
\hline Number of 2 & 235 \\
\hline Number of 3 & 65 \\
\hline Number of P & 12 \\
\hline Total & 498 \\
\hline Rate of filling & $49.52041 \%$ \\
\hline
\end{tabular}

The matrix rate of filling is equal to the number of boxes of 1 by the total number of boxes.

Table 4: Stability Iterations of the DIM

\begin{tabular}{c|c|c}
\hline Iteration & Influence & Dependence \\
\hline 1 & $88 \%$ & $94 \%$ \\
\hline 2 & $102 \%$ & $102 \%$ \\
\hline 3 & $100 \%$ & $99 \%$ \\
\hline 4 & $100 \%$ & $100 \%$ \\
\hline
\end{tabular}

If proved that each matrix should converge to stability within a certain number of iterations (generally 4 or 5), these iterations then allow to classify the influences and the dependencies and the variables of the DIM matrix.

The above classification consists of summing up the row variables intensity as well as for the column variable. The variable most influencing the others (row sums) are called key variable of the system: the financial system: public spending, the regulation, foreign reserves, price of the oil barrel, unemployment, inflation and SMEs. 
Table 5. Key Variables of the System

\begin{tabular}{|c|c|c|c|}
\hline $\mathbf{N}^{\circ}$ & Variable & Column's total & Row's total \\
\hline 1 & Active population & 40 & 34 \\
\hline 2 & Capital & 40 & 36 \\
\hline 3 & Foreign reserves & 36 & 34 \\
\hline 4 & IT & 40 & 29 \\
\hline 5 & Inflation & 39 & 35 \\
\hline 6 & SME & 52 & 29 \\
\hline 7 & Public spending & 50 & 41 \\
\hline 8 & Business climate & 20 & 27 \\
\hline 9 & Financial system & 32 & 36 \\
\hline 10 & Regulation & 51 & 41 \\
\hline 11 & FDI & 40 & 31 \\
\hline 12 & External trade & 45 & 31 \\
\hline 13 & Financial crisis & 16 & 23 \\
\hline 14 & External debt & 22 & 27 \\
\hline 15 & Informal sector & 37 & 32 \\
\hline 16 & Exchange rate & 12 & 37 \\
\hline 17 & Interest rate & 30 & 18 \\
\hline 18 & National security & 23 & 42 \\
\hline 19 & Geographic localisation & 0 & 8 \\
\hline 20 & Demographic growth & 14 & 25 \\
\hline 21 & Literacy rate & 22 & 23 \\
\hline 22 & Innovation $R \& D$ & 21 & 20 \\
\hline 23 & Economic system & 32 & 50 \\
\hline 24 & Unemployment & 44 & 32 \\
\hline 25 & Saving & 32 & 17 \\
\hline 26 & Currency & 23 & 31 \\
\hline 27 & Price of barrel & 10 & 39 \\
\hline \multirow[t]{2}{*}{28} & Occupied population & 28 & 25 \\
\hline & Totals & 851 & 851 \\
\hline
\end{tabular}

\section{RESULTS}

\subsection{Descriptive Statistics}

This plan represents the influences and dependencies between variables. Variables' coordinates are the sums of influences and dependencies reckoned starting from the DIM matrix. It is, therefore, to show the most influential variables and the most dependent in the near past. The plan could be divided into five sectors:

- Sector 1: Variables carry on a strong influence and are less dependent, they are explanatory variables conditioning the remaining system: saving and the interest rate.

- Sector 2: Variables are both influential and strongly dependent, these are shift variables unstable by nature. Each action on these variables will have incidences on the others and a feedback effect on themselves: public spending, external trade (import/export), SMEs, the regulation, unemployment, FDI, active population, informal sector, IT, inflation, capital, foreign reserves, financial system and the economic system.

- Sector 3: Variables are less influential and strongly dependent, these are result variables. Their evolution could be explained by other variables of the sector 1 and 2 (national security and exchange rate).

- Sector 4: Variables are both less influential and less dependent, relatively disconnected from the system. We call them autonomous variables: literacy rate, geographical localization, innovation R\&D, financial crisis.

- Sector 5: Variables are moderately influential or dependent, called squad variables (determinant): external debt, business climate, demographic growth, the price of the oil barrel, currency. 
Figure 1. Plan of Direct Influence /Dependence

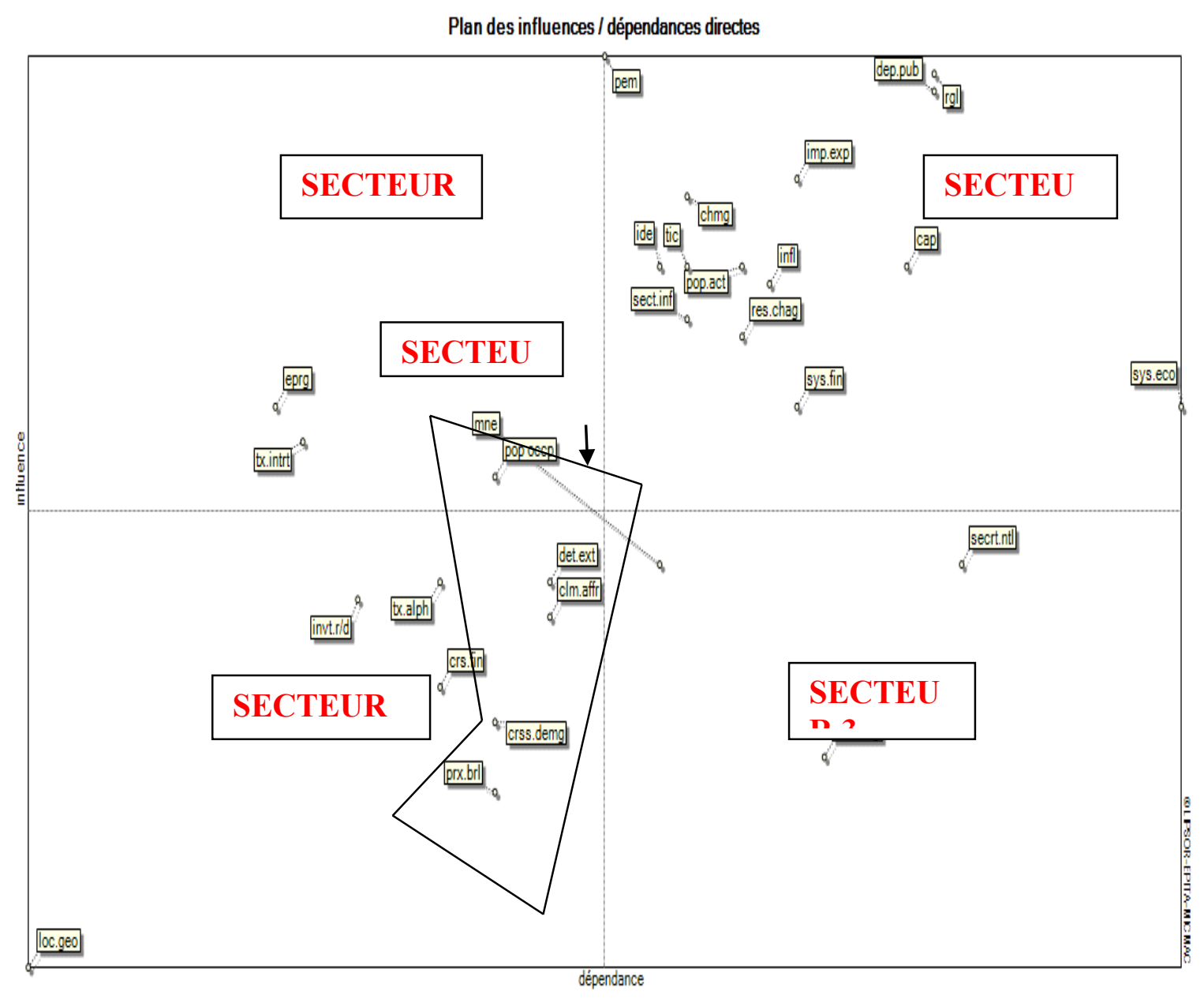

The matrix of Indirect Influences (MII) provides a new classification of variables showing the most important of the system. Indeed, we detect hidden variables. The plan of indirect influences represents indirect influences and dependencies between variables and the coordinates corresponding to the sums of influences and dependencies, reckoned from the MII matrix. 
Figure 2. Plan of Indirect Influences / Dependencies

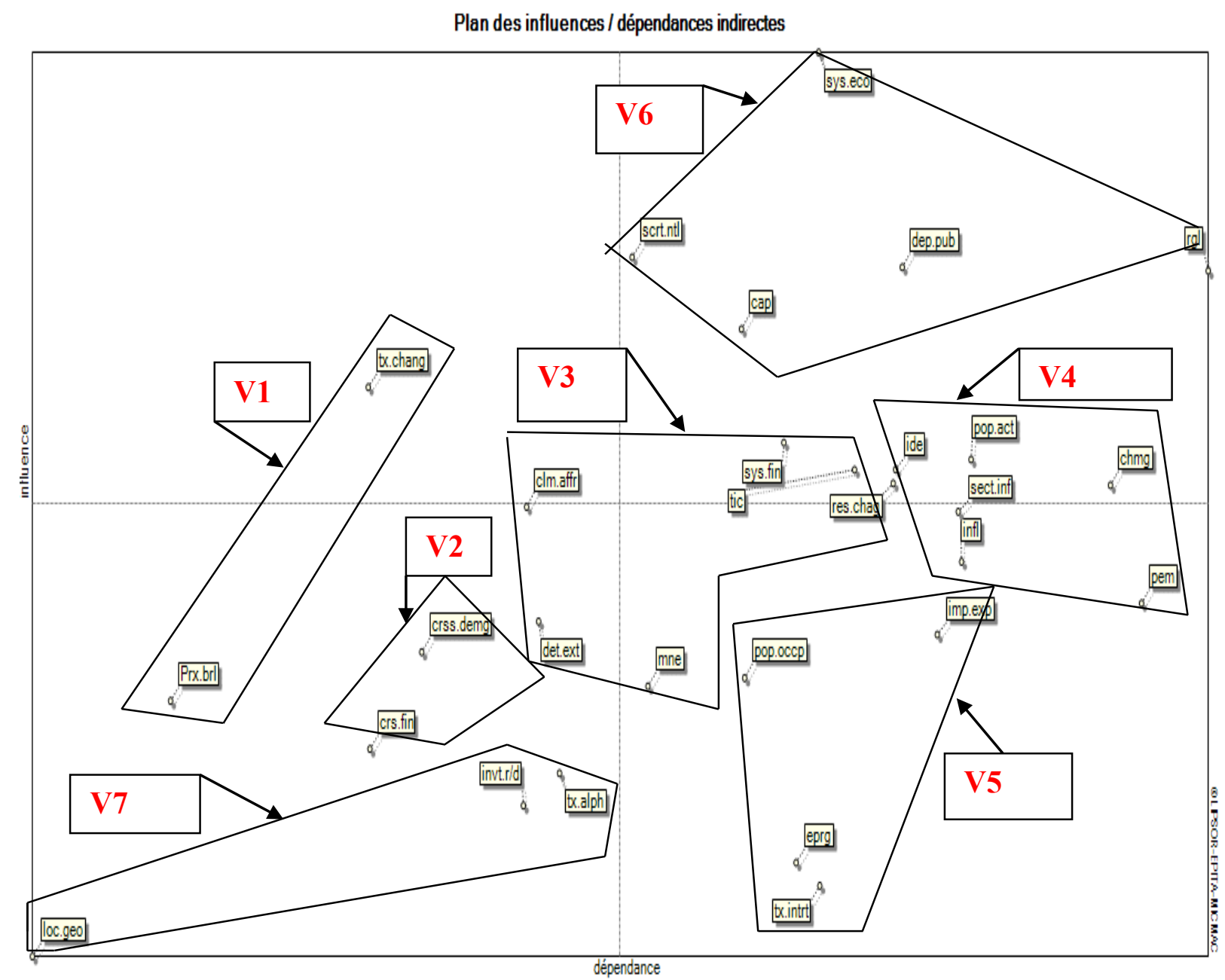

We notice from this plan that the system (Algerian economic growth) is Unstable and changing system with variables distributed in the second cross line with a few input/output variables. Key variables evolve the system without coherence, making it unmanageable. This instability is the origin of oppositions and instabilities of the systems' actors. Hence, we can determine from this plan the set of variables influencing the Algerian economic growth:

- Input Variables (V1), these variables will determine the system's performance. Was the $\underline{\text { Price of oil }}$ barrel: an variable for an environment-based scenario: its external characteristic makes it dependent on the system, and by contrast determinant of the system's scenarios. The Algerian economy remains dependent on oil revenues, $97 \%$ of exporting revenues and $70 \%$ of the State's budget come from the oil revenues. The exchange rate In 2011, the Dinar was traded as follows :1 US Dollar $=72.39$ DA, 1 Euro $=102.51 \mathrm{DA}$ and the Shift variables, which are intermediary variables. Moderately influential and dependent. They account for the system regulation.

- The Second Variables (V2): they can have a long-run effect or accompanying the evolutions: External debt: the gross external debt of Algeria stands for only $2.4 \%$ of GDP in 2012, and is expected to maintain in 2013. Demographic growth: Algerian population growth rate is $1,44 \%$ (after being $3,14 \%$ in 1971-1980). Financial crisis: its impact is minor as the budget deficit was just $4 \%$ of GDP in 2011.

- The Regulators (V3): They intervene in the functioning of the system, constituting good indicators for 
the system's evolution. They are: Business climate: Algeria engaged reforms to facilitate creation of businesses and improve the framework related to these activities: revising the commerce code, obtaining commerce registries, relieving tax pressures on businesses. Financial system: absence of a foreign exchange market, the direct intervention of the Bank of Algeria (revising the credit and money act) are due to the inefficiency of the system. Foreign reserves: Foreign reserves knew a sharp increase of more than 110.18 billion us dollar in 2007, end-2012 forecasts are about 205.2 billion us dollar.

- Output Variables: They translate the consequences and the results of the system's actors.

- The Objectives (V4): They enable to define medium-long term points for the system evolution: $F D I$ : Algeria is less attractive for the FDI following restrictive measures toward investors: the 51-49 investment rule, the examination of every foreign investment by the National Investment Council, obligation to open the social capital to Algerian partners. Active population, unemployment: Unemployment hit youth population with a rate of $21.5 \%$ for the aged between 15 and 24 years old. Inflation: recorded a significant increase following wage increase and tensions on foodstuff prices, the inflation rate are expected to recede to $5 \%$ in 2013.

- SMEs: Private companies contribute to $75 \%$ of the non-hydrocarbon GDP and by $55 \%$ in the added value, the number of SMEs increases despite the inadequate environment, passing from 180,000 in 2001 to 600,000 in 2011.

- The Sensitive Variables (V5): They interpret the final frequencies of the evolutions : Currency: following sharp wage increase in the public administration, the State operated a $10 \%$ devaluation of the Dinar vis-à-vis the Euro and the US Dollar. Occupied population: it passed from 6 million people in 2006 to 9.3 million in 2009. Saving, interest rate: the Algerian banking system contributes poorly to the economy's need of funding. External trade: Algerian exports reached 61.6 billion US Dollar in 2012, while imports slowed by $3.6 \%$ to 38.4 billion US Dollar, generating a trade surplus of 23.2 billion US Dollar.

- The Issues (V6) : key variables. They are at the heart and the origin of the system's evolution. : National security: it improved despite terrorist attacks (case of Tiguentourine) and the recent social strikes. Economic system: the economic policies seem to strengthen protectionism measures against FDI and imports (51-49 investment rule, 25\% tax on bonuses, 30\% Customs duties. Public spending: 286 billion US Dollar allocated to the 2010-2014 public investment plan in addition to many subsidies which account for $32 \%$ of GDP.

- Autonomous Variables (V7): these are variables weakly connected to the system. They are not determinant for the system future: The geographical localization: exploitation of natural resources, strategic location and the climate. The literacy rate and innovation $R \& D$ : despite a $97 \%$ rate of school enrollment (8 million pupils) and more than 1.3 million students, the education quality remains weak and needs an improvement (the university rankings shows this recommendation). 
Figure 3 illustrates the series of relationships between variables influencing the Algerian growth and their indirect influence.

- Figure 3. Indirect Influences
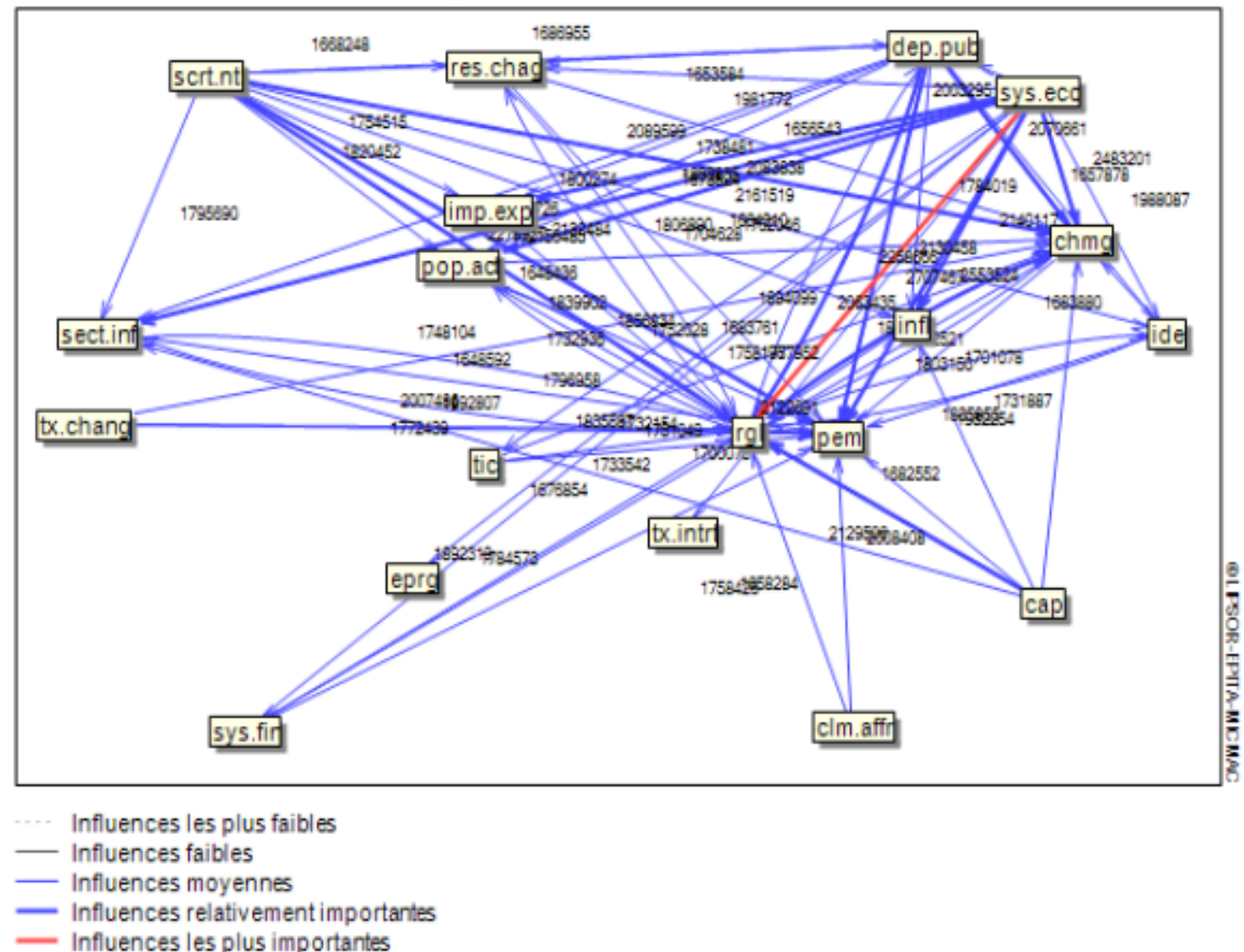

We notice a set of influences: Most important influence is the influence of the economic system on the regulation. The Relative important influences which are the influence of foreign reserves on public spending, national security on regulation and SMEs, the economic system on the informal sector and on external trade. The Moderate influences which are the national security on the informal sector, the exchange rate on unemployment. And the Weak influences which are the IT on unemployment.

\subsection{Results Of Structural Analysis}

First, determining key variables of the system, In this classification we will determine the most influent variables (key variables of the system) on the Algerian economic growth. 
Figure 4. Classification of Indirect Influences

\begin{tabular}{|c|c|c|}
\hline Rang & Variable & Variable \\
\hline 1 & $23 \cdot$ sys.eco & $23 \cdot$ sys.eco \\
\hline 2 & $18-s c r t . n t l$ & $18 \cdot$ scrt.ntl \\
\hline 3 & 7 -dep.pub & 7 -dep.pub \\
\hline 4 & $10 \cdot r g$ & $10 \cdot r g$ \\
\hline 5 & 2- cap & $2 \cdot \operatorname{cap}$ \\
\hline 6 & $16 \cdot$ tx.chang & $16 \cdot$ tx.chang \\
\hline 7 & 9-sys, fin & 9-sys.fin \\
\hline 8 & $3 \cdot$ res.chag & 1-pop.act \\
\hline 9 & 1-pop.act & 11 - ide \\
\hline 10 & $4-$ tic & $4 \cdot$ tic \\
\hline 11 & $24 \cdot$ chmg & 3.res.chag \\
\hline 12 & 11 - ide & $24 \cdot$ chmg \\
\hline 13 & $5 \cdot$ infl & 8.clm.aff \\
\hline 14 & $15 \cdot$ sect.inf & $15 \cdot$ sect.inf \\
\hline 15 & $6 \cdot$ pem & 5 - infl \\
\hline 16 & 8.clm. afft & 6.pem \\
\hline 17 & 12 - imp,exp & 14 - det.ext \\
\hline 18 & 14 - det.ext & 12 - imp.exp \\
\hline 19 & 20 - crss.demg & 20 - crss.demg \\
\hline 20 & 26 - mne & $28 \cdot$ pop.occp \\
\hline 21 & $28 \cdot$ pop.occp & $26 \cdot \mathrm{mne}$ \\
\hline 22 & $13 \cdot \mathrm{crs}$. fin & 27 - Prx.brl \\
\hline 23 & 27 - Prx.brl & $13 \cdot \mathrm{crs}$ fin \\
\hline 24 & $21 \cdot$ tx.alph & $21 \cdot$ tx.alph \\
\hline 25 & $22 \cdot$ invt. $/$ d & 22 - invt.r/d \\
\hline 26 & $17 \cdot$ tx.intrt & $25 \cdot$ eprg \\
\hline 27 & 25 - eprg & $17 \cdot$ tx. intrt \\
\hline 28 & $19 \cdot$ loc.geo & $19 \cdot$ loc.geo \\
\hline
\end{tabular}

The above figure brings to light the following classification:

- The Direct Classification, It tells the direct picture of the factors' importance giving the situation of the Algerian growth: the economic system, the national security, public spending, capital, the regulation, the exchange rate and the financial system.

- The Indirect Classification or MICMAC, It allows to relativist the immediate importance of certain phenomenon and gives the actual situation bear in mind the ongoing evolution process. The indirect classification of the influential variables on the economic growth permits to reveal the following variables: the economic system, national security, public spending, capital, regulation, exchange rate and the financial system. Green lines represent the changing location of variables upward when variables move upward it means they have strong indirect influence: Business climate (from $16^{\text {th }}$ to the $13^{\text {th }}$ position) : some specific measures adopted for the business climate: reducing the number of papers necessary to create businesses. $\underline{F D I}$ (from $12^{\text {th }}$ to the $9^{\text {th }}$ position) won 4 positions: new measures on the foreign investments framework might be a hinder to national and foreign private investments. The price of oil barrel: The Algerian economy remains heavily relying on the hydrocarbon sector (37\% of GDP in 2011) and to the evolution of oil prices ( the average price was 107 US Dollar/barrel, up from 77 US Dollar/barrel in 2010) . The active population, the occupied population (won one position): these variables express the urgent need to take care of social conditions in terms of training, social security. The external debt: Algeria improved its external debt sustainability that is estimated to be 5.4 billion US Dollar in 2009 (2.7\% of GDP). Red lines show less influential variables: Unemployment: the unemployment rate diminished from $30 \%$ in 2000 to $10 \%$ in 2010 . SMEs: continuing reforms to improve Algeria's business climate favoring the SMEs creation: easing 
access to funding and improve administrative procedures. Inflation: Inflation remains subdued thanks to the prudent monetary policy adopted by the Bank of Algeria. The inflation rate was $4 \%$ to $5 \%$ in 2011. Currency: as it is an output variable (sensitive) undergoing the changes of other variables as the money and credit act. Financial crisis: the financial crisis did not impact our economy in a direct way because of the low budget deficit (3.7\% of GDP in 2012) and the oil revenues.

- The Classification of Indirect Influence and Indirect Potential permits to determine the most influential on the Algerian economic growth by 2025 (figure.5). The indirect potential classification was obtained by taking account of the direct and indirect relations, the effects of the potential relations associated to new variables or to possible breaks at the horizon of study. In this classification, we determine the most influent variables (key variables of the system) on the Algerian economic growth by 2025. Economic system: remains a determinant, and we record it by the State's return to production activities. This option seems a direction of the new programs expecting important investments on upgrading the industrial sector, the revitalization of big public industrial groups as SNVI (engines), SAIDAL (pharmaceutics), ENIE (electronics), PMA (agriculture machinery) and ENMTP (public construction). Public spending: finishing big projects already launched, especially in transportation (railroads, highways), water and energy, and the launching of new projects: realizing 2 million houses, the east-west highway, water transfer in the southern region. Regulation (from $4^{\text {th }}$ to the $2^{\text {nd }}$ position): The main weaknesses are at the level of instability of the legal framework, long administrative procedures, and SMEs difficult access to banking funding, rigid labor legislation, and complex fiscal procedures. Foreign reserves (won 4 positions: from the $8^{\text {th }}$ to the $4^{\text {th }}$ ) Algeria's foreign reserves to reach 205 billion US Dollar in the coming years which ensures funding big investment programs and improve the social conditions of the population. Unemployment (from the $11^{\text {th }}$ to the $8^{\text {th }}$ position): Algeria still faces major social challenges related to unemployment. Algeria's inflation rate remains the highest among the Mediterranean countries (Algeria's methodology to determine unemployment does not obey ILO norms and overestimate its rate). FDI (from $12^{\text {th }}$ to $11^{\text {th }}$ position): Government policy to deter foreign investors especially the one limiting the foreign participation to $49 \%$ when realizing partnerships with local companies. Inflation (from $13^{\text {th }}$ position to the $9^{\text {th }}$ : won 4 positions): Inflation level to see a mild increase due to wage increases and retirement pensions, a spike in world foodstuff markets (cereals, sugar, milk). Business climate (from $16^{\text {th }}$ to the $14^{\text {th }}$ position): it constitutes the important constraint impeding the growth in Algeria as a set of regulations slow down the private activity (the variable regulation expresses this trend). Currency (from $20^{\text {th }}$ to the $17^{\text {th }}$ position): The Bank of Algeria intervenes to weaken the currency to control inflation (inflation is one of the obstacles to economic recovery) and to reduce imports. The price of barrel (from $23^{\text {th }}$ position to the $18^{\text {th }}$ : won 5 positions): The economy relies heavily on the hydrocarbon sector and remains vulnerable to external shocks (production slowing down, new sources of energy as shale gas and the great gas potential in Russia, OPEC quotas), oil revenues and high oil prices are government obstacles to pass reforms to diversify the economy. Moreover, the red lines illustrate the diminution of certain variables' influence at the same horizon of study. National security: The set of measures trying to improve the security: national reconciliation, peace charter, cooperation against terrorism with other countries. These will improve the investment climate. Exchange rate, interest rate, and the financial system: inadequate efficiency of the banking/financial sector impede the needs of funding for the national economy. Active population: its influence remains persistent following the inadequate training, its aptitude for changing and the entrepreneurship spirit, multitude of social problems: healthcare, poverty, education. Informal sector: recent measures implemented by the government (building ne markets, helping traders by fiscal incentives, simplifying commerce registry procedures) will diminish the size of the informal market. SMEs: The business climate constitutes a hinder for the private sector development and the creation of SMEs notably the access to funding, administrative procedures, fiscal taxes on companies. External $\underline{\text { debt }}$ : Algeria follows a prudent management of its debt thanks to prudent foreign reserve placement. The oil revenues could offset the impact of external debt. 
Figure 5. Classification of Indirect Influence / Indirect Potential

\begin{tabular}{|c|c|c|}
\hline Rang & Variable & Variable \\
\hline 1 & 23 - sys.eco & 23 - sys.eco \\
\hline 2 & 18 - secrt.ntl & اgr - \\
\hline 3 & $7 \cdot$ dep pub & 7 - dep.pub \\
\hline 4 & $10-\mathrm{rgl}$ & 3-res,chag \\
\hline 5 & 2- cap & 18 - secrt.ntl \\
\hline 6 & 16 - bx.chang & 2-cap \\
\hline 7 & 9 - sys.fin & 16 - tx.chang \\
\hline 8 & 3 - res.chag & 24 - chmg \\
\hline 9 & 1 - pop.act & 5 - infl \\
\hline 10 & $4-$ tic & 9 - sys.fin \\
\hline 11 & 24 - chmg & 11 - ide \\
\hline 12 & 11 - ide & 1 - pop.act \\
\hline 13 & 5 - infl & 4 - tic \\
\hline 14 & 15 - sect. inf & 8 - clm. affr \\
\hline 15 & 6. pem & 15 - sect inf \\
\hline 16 & 8- clm. affr & $28 \cdot p o p, 0 c c p$ \\
\hline 17 & 12 - imp.exp & 26 - mne \\
\hline 18 & 14 - det. ext & 27 - prx.brl \\
\hline 19 & 20 - crss.demg & 6-pem \\
\hline 20 & 26 - mne & 14 -det.ext \\
\hline 21 & 28 - pop.occp & 12 - imp.exp \\
\hline 22 & 13 - crs.fin & 20 - crss.demg \\
\hline 23 & 27 - prx.brl & 13 - crstin \\
\hline 24 & 21 - tx.alph & 21 - tx.alph \\
\hline 25 & 22 - invt.r/d & 22 - invt $r / d$ \\
\hline 26 & $17=t \times$ intrt & 25 - eprg \\
\hline 27 & 25 - eprg & $17=t \times$ intrt \\
\hline 28 & $19-100,960$ & $19-100,960$ \\
\hline
\end{tabular}

\section{CONCLUSION}

After different steps of applying structural methods that allow showing essential variables in the process of Algerian economic growth, during the three periods of time, we obtain the following results:

- The near past: the price of the oil barrel, the economic system, unemployment, public spending, regulation, foreign reserves, inflation and SMEs.

- The actual period: the price of the oil barrel, the economic system, business climate, FDI, active population, occupied population, external debt. Also, other variables have a less influence: unemployment, SMEs, inflation and external trade.

- The long term (the horizon of 2025): foreign reserves, inflation, economic system, public spending, regulation, unemployment, FDI, business climate, currency, occupied population, the price of the oil barrel and saving. Other variables have a moderate influence: national security, capital, exchange rate, financial system, active population, IT, informal sector, SMEs, external trade, demographic growth, interest rate, and external debt.

\section{AUTHOR BIOGRAPHY}

Rachid Toumache is an Assistant Professor of Economics at National High School of Statistics and Applied Economics of Algeria. His research topics include Time Series, Econometrics and Modeling of Macroeconomics. He has published his recent article in referred Journal such as Journal of Business and Retail Management Research (JBRMR), Vol. 9 Issue 1,pp.64-72. (www.jbrmr.com) (Indexed by SCOPUS) [UK].

Khaled Rouaski is an Assistant Professor of Economics at National High School of Statistics and Applied Economics of Algeria. His research topics include Applied Economics, Development Economics and Digital Economics. he has published his recent article in referred Journal such as Journal of Business and Retail Management Research (JBRMR), Vol. 9 Issue 1,pp.64-72. (www.jbrmr.com) (Indexed by SCOPUS) [UK]. 


\section{REFERENCES}

Ben Youssef, A., Chaibi, A ., and Ben Aoun, L.P.,(2015). E-Skills, Brains And Performance Of The Firms: ICT And Ability Of Firms To Conduct Successful Projects In Luxembourg. The Journal of Applied Business Research. Volume 31, Number 3:pp.781 - 794.

Ben Youssef, A., Hadhri, W., and Mhenni, H., (2012b). Intra-firm diffusion of innovation: Evidence from Tunisian SME's regarding Information and Communication Technologies. Middle East Development Journal.Volume 3, Issue 3 : pp. 75-97.

Brend, B., (1993). le tiers monde croissance, développement, inégalité . Paris : Edition ellipses.

Burgenmeier, B., (2005). Economie du développement durable . $2^{\mathrm{em}}$ Edition. Paris : Boeck Université.

Cologni, A., Manera, M., (2009). The asymmetric effects of oil shocks on output growth: A Markov-Switching analysis for the G-7 countries. Economic Modelling. Volume 26 :pp.1 - 29.

Cuaresma, J.C., Lábaj, M., Pruz insky', P., (2014). Prospective ageing and economic growth in Europe. The Journal of the Economics of Ageing. Volume 3:pp $50-57$.

Durance, P., Godet, M., Mirenowicz, P., (2007) . La prospective territoriale: Pour quoi faire? Comment faire? . Cahiers de LIPSOR N ${ }^{\circ}$. Paris :Edition GERPA .

Gallouj, F., and al., (2015). The futures of the service economy in Europe: A foresight analysis. Technological Forecasting \& Social Change. volume 94 :pp. 80-96.

Godet, M., (1997). Manuel de prospective stratégique: l'art de la méthode. Tome 2 :Paris : Edition DUNOD.

Godet, M., (2004). La boite à outils de prospective stratégique . Cahier du LlPSOR . Paris : Edition GERPA.

Gonod, P., (1996). Dynamique Des Systemes Et Methode De Prospective. Travaux Et Recherches De Prospective . Futurible international . $\mathrm{N}^{\circ} 136$.

Greene, W., (2005). Econométrie. New York : $5^{\text {éme }}$ Edition . New York : University .

Johansen, S., (1991). Estimation and Hypothesis Testing of Cointegration Vectors in Gaussian Vector Autoregressive Models. Econometrica. Vol 6. No 59 : pp. 1551-1580.

Jouvenel,H., (1993). Sur la méthode prospective, un bref guide méthodologique. № 179 . Paris : Edition Futuribles .

Lardic, S., (1988) . Econométrie des séries temporelles macroéconomiques et financières . Paris: Economica.

Lardic, S . Mignon, V. , (2002) . Econométrie des séries temporelles macroéconomiques et financières. Paris : Economica.

Lardic, S., Mignon, V., (2002) . Econométrie des séries temporelles macroéconomiques et financières. Paris : Economica.

Maamar ,S., Abid, M. , (2012). Energy use for economic growth:A trivariate analysis from Tunisian agriculture sector. Energy Policy. volume 48 : pp.711-716.

Mélard, G. , (2002). Méthodes de prévision à court terme. Paris : Ellipses.

Nashachibi ,K. et al., (1998). Algérie, Stabilisation et transition à l'économie de marché. Washington : FMI.

ONEDD., (2002). L'Observatoire national de l'environnement et du développement durable . Paris : Edition MATE .

Paleologos , J.M., Polemis, M.L., (2013). What drives investment in the telecommunications sector? Some lessons from the OECD countries. Economic Modelling. volume 31 :pp. 49-57.

Pradhan, R.P ., and al., (2014). Economic growth and the development of telecommunications infrastructure in the G-20 countries: A panel -VAR approach. Telecommunications Policy. volume 38 :pp. $634-649$.

Rouaski, K ., Toumache, R., and Talbi, B., (2014). The Impact Of Augmentation Wages Public Based On The Purchasing Power Of Households In Algeria. International Journal of Business \&Economic Development (IJBED).Vol 2, No 1: pp. 64 69.

Schmidtc, C., (1991). Prospective Industrielle Et Theorie Des Jeux: Element Pour Un Renouvellement Methodologique . Economie appliquée .Tome XIVI . N4.

Schw ,A., (1993). La planification stratégique par scénarios. Futurible. $\mathrm{N}^{\circ} 176$.

Toumache, R. Rouaski, K., and Talbi,B., (2013). Analysis by Panel Data Method Estimation of Car Fleet Models. International Journal of Scientific and Research Publications, Vol. 3, No.6.

Toumache, R., Rouaski, K., and Talbi,B., (2014). The impact of fluctuating oil prices on inflation in Algeria. Journal of Business and Retail Management Research (JBRMR). Vol 9, Issue 1: pp.64 -71.

Zakane, A. ,2005. Dépenses publiques productives et dynamique de croissance, approches théoriques et empiriques appliquée au cas de l'Algérie “. Papier Presenter dans le Seminaire Internationale La Problematique De La Croissance Au Pays Du MENA, Universite D’Alger. 


\section{NOTES}

